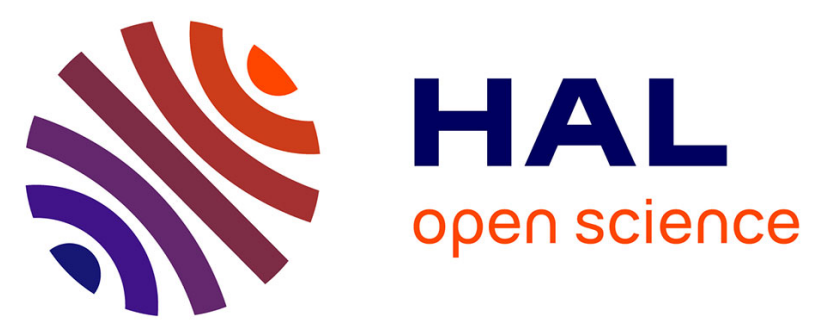

\title{
Another vision of sound tree and forest management : insights from traditional ash shaping in the Moroccan Berber mountains
}

Didier Genin, Soufiane M'Sou, Abderrahim Ferradous, Mohamed Alifriqui

\section{- To cite this version:}

Didier Genin, Soufiane M'Sou, Abderrahim Ferradous, Mohamed Alifriqui. Another vision of sound tree and forest management: insights from traditional ash shaping in the Moroccan Berber mountains. Forest Ecology and Management, 2018, 429, pp.180-188. 10.1016/j.foreco.2018.07.018 . hal02093825

\section{HAL Id: hal-02093825 \\ https://hal-amu.archives-ouvertes.fr/hal-02093825}

Submitted on 9 Apr 2019

HAL is a multi-disciplinary open access archive for the deposit and dissemination of scientific research documents, whether they are published or not. The documents may come from teaching and research institutions in France or abroad, or from public or private research centers.
L'archive ouverte pluridisciplinaire HAL, est destinée au dépôt et à la diffusion de documents scientifiques de niveau recherche, publiés ou non, émanant des établissements d'enseignement et de recherche français ou étrangers, des laboratoires publics ou privés. 
archives-ouvertes

\title{
Another vision of sound tree and forest management: Insights from Traditional Ash Shaping in the Moroccan Berber Mountains
}

\author{
Didier Genin, Soufiane M \\ apos;sou², Abderrahim Ferradous, Mohamed Alifriqui
}

\section{To cite this version:}

Didier Genin, Soufiane M

apos;sou ${ }^{2}$, Abderrahim Ferradous, Mohamed Alifriqui. Another vision of sound tree and forest management: Insights from Traditional Ash Shaping in the Moroccan Berber Mountains. Forest Ecology and Management, Elsevier, 2018, 429, pp.180-188. <10.1016/j.foreco.2018.07.018>. < hal-02093825>

\section{HAL Id: hal-02093825 \\ https://hal-amu.archives-ouvertes.fr/hal-02093825}

Submitted on 9 Apr 2019

HAL is a multi-disciplinary open access archive for the deposit and dissemination of scientific research documents, whether they are published or not. The documents may come from teaching and research institutions in France or abroad, or from public or private research centers.
L'archive ouverte pluridisciplinaire HAL, est destinée au dépôt et à la diffusion de documents scientifiques de niveau recherche, publiés ou non, émanant des établissements d'enseignement et de recherche français ou étrangers, des laboratoires publics ou privés. 


\title{
Another vision of sound tree and forest management: Insights from Traditional Ash Shaping in the Moroccan Berber Mountains
}

Didier Genin $^{1}$, Soufiane M'Sou², Abderrahim Ferradous ${ }^{3}$, Mohamed Alifriqui $^{4}$

1: IRD, Laboratoire Population, Environnement, Développement, UMR151 AMU-IRD, Marseille, France, didier.genin@ird.fr * Corresponding Author: Aix-Marseille Université, Centre Saint-Charles, LPED, Case 10, 13331 Marseille cedex 03, France

2 : Department Environment \& Ecology. Faculté Semlalia, Université Cadi Ayyad, Marrakesh, Morocco Université Cadi Ayyad. soufiane.ms@yahoo.fr

${ }^{3}$ : Centre de Recherche Forestière, Marrakesh, Morocco. ferabder@yahoo.fr

${ }^{4}$ : Department Environment \& Ecology. Faculté Semlalia, Université Cadi Ayyad, Marrakesh, Morocco Université Cadi Ayyad, Dept. alifriqui@gmail.com

\begin{abstract}
:
The dimorphic Ash tree (Fraxinus dimorpha) is a keystone species in the functioning of agrosylvo pastoral systems and livelihoods found on the northern slopes of the Atlas Mountains of Morocco. It grows in spontaneous woodlands and forests which are fully integrated within agro-ecosystems. Local populations have for centuries shaped ash stands by sequentially trimming and pollarding individual trees for providing fodder, house roof building material and ecosystem services for the overall social-ecological system. Exploitation follows very strictly observed 4-year cycles of exploitation of pollarded trees, which allows the harvesting of each individual tree for foliar forage after 4 years of regrowths, and at the same time
\end{abstract}


shaping and letting some well-grown branches develop for further cycles in order to provide diameter-standardized poles (after 8 years) and beams (after 28-32 years) for house roof construction. The management of tree regeneration is also illustrative of deep-seated Traditional Ecological Knowledge. Overgrazed trees or new seedlings are protected by means of stone walls. Resprouts with the most vigorous and straightest stems are selected and linked to each other, in order to favor, when growing, trunk anastomosis. This highly original practice allows an increase in foliage production of $36 \%$ after a 4-year cycle, compared to non-anastomosed trees, and promotes the resilience and longevity of the trees. The main discrepancies in the vision of what might constitute 'good' forest management between local stakeholders and professional foresters concern 1) the scale of the management unit (individual trees and overall forested landscape vs tree stand), 2) the partial (diffuse) exploitation of living trees vs intensive cycles of exploitation of the whole tree stand, and 3) flexibility and pro-active management of heterogeneity vs homogenization. This perspective offers an alternative basis for rethinking forest management strategies in a context of global change, and original insights for conserving anthropized forest ecosystems without excluding people.

Keywords: Traditional Ecological Knowledge, Rural Forest, Agroforestry parkland, Pollarding, Anastomosis, Tree management. 


\section{Introduction}

There are recurring questions regarding the ecological sustainability of resource management within traditional rural societies, and the underlying significance and rationale of practices related to this knowledge. Hence, Traditional Ecological Knowledge has been the object of renewed interest during the last four decades, both as a feature of human cultural patrimony (Auclair et al. 2011), and as a basis for rethinking innovative forest management practices (Parotta \& Agnoletti 2007). At the same time, well-established scientific postulates such as desertification and af- or de- forestation processes, have sometimes been questioned in the light of their long-term effects on the environment, and new approaches concerning the place of human beings in the ecosystems (Davies 2005, Fairhead \& Leach 1995). More generally, it is the place of humans in the ecosystem and their impact that have been the focus of intensive debate. Although numerous studies have clearly demonstrated that human activities could lead to dramatic environmental and biodiversity destruction (Soule 2013), several authors have argued that anthropogenic impacts are not to be considered in a monolithic way, since they can lead, in certain circumstances, to conservation and enhancement of biodiversity and ecosystem functioning (Siebert \& Belsky 2015). This point of view has been in particular put forward with regard to the Mediterranean region, a hotspot of biodiversity associated with a long-standing intensive human use and disturbance (Blondel 2006, Gauquelin et al. 2018). At a more local scale, very few studies have tried to detail concretely the actual mechanisms at work in shaping sustainable cultural practices based on traditional knowledge (Blanco et al. 2015).

Trees and forests, due to the diversified resources they offer, their longevity and their leading ecological role with regard to the functioning of highly representative ecosystems, constitute interesting models to shed light on the human-environment interactions that have been woven 
at a local scale for millennia in traditional rural societies (Szabo 2010). In particular, the exploitation of living trees without destroying them, usually considered as depredatory practices, has been shown to present certain advantages in terms of enhancing their biological development and their conservation (Turner et al. 2009). These Culturally Modified Trees (CMT) are embedded within diversified systems of belief and perception, which also enshrine preservation and conservation insights resulting from observation and experience (Turner et al. 2000). However, their usual primary function is to provide diversified resources which contribute to the livelihoods and resilience of local societies. They also provide ecosystem services at different scales, from individual parts of the tree to the overall rural landscape.

For all these reasons, trees and forest patches have historically always been included within agro-forestry and land use systems world-wide, at times when human societies were highly dependent upon local natural resources. In some regions, such as Europe (Slotte 2001, Petit \& Watkins 2004), these practices have been mostly lost. In other areas, such as Asia (Singh et al. 2015), they are still alive, and contribute to the livelihood of millions of people. In Morocco, trees and forests have been and still are the pillard of several traditional farming systems. Endemic Argan (Argania spinoza) forest, widely known because of the famous cosmetic oil it produces, is a well-known example of a co-evolved human-tree ecosystem (McGregor et al. 2009) that presents all the characteristics of what may be called rural (Genin et al. 2013) or domestic (Michon et al. 2007) forests. In most parts of Morocco, diversified agroforestry systems have been developed. This is particularly the case in the mountains of the High Atlas, where original traditional practices are commonly found for managing forest resources for combined fodder and timber production (Hammi et al. 2010; Genin and Simenel 2011; Genin et al. 2016). It would appear that the case of the very sophisticated management system associated with the use of Fraxinus dimorpha, a native ash tree spontaneously growing in some parts of the Moroccan High Atlas, has not yet been documented. However, management 
practices involved are highly original, particulaly those linked to promote twig coalescence, and could offer valuable insights as a basis for devising alternative forest management strategies in other regions.

The aim of this article is hence to describe and analyze traditional practices of shaping the dimorphic ash tree found in the Berber High Atlas mountains of Morocco for both foliage and living wood exploitation and tree regeneration. We hypothesized that apart from this tree being a keystone species with regard to agro-pastoral livelihoods, these practices are ecologically sound for its long-term conservation, socially effective in promoting long-term continuous agro-pastoral activities, and could offer some interesting more general insights for alternative approaches to planting for the purposes of tree and forest management.

\section{Material and Methods}

2.1.Native dimorphic ash stands in the High Atlas mountains and study site

Fraxinus dimorpha is called 'Imts' in the Berber language. It is a tree species native to the mountains of North Africa and Central Asia. It occupies a particular ecological niche in the central High Atlas, being located mainly at the bottom of rocky slopes and ravines with temperature inversions, at an altitude between 1200 and $2000 \mathrm{~m}$. The dimorphic ash tree is characterized by two types of leaves, depending on the development stage of the tree and the level of browsing. It is typically a multi-functional tree for the local community, providing firewood, timber mainly for the roofs of houses and agricultural tools, food (spices) and medicinal products, and its leaves are used for dyeing textiles. But the most critical use is as fodder in the autumn (end of August to November), in a period when standing range forage is scarce and dry (Genin et al. 2016). 
Ash tree stands constitute fragmented wooded areas throughout the Atlas, covering less than $5 \%$ of the total forested area. We focused our investigations on the rural district (Commune) of Ait M'Hamed, located in the Central High Atlas, Azilal Province, where the dimorphic ash is the most widespread tree species in the landscape (Figure 1). The altitude ranges from 1300 to $1700 \mathrm{~m}$. The climate is Mountain Mediterranean with annual rainfall between 450 and 600 $\mathrm{mm}$, a mean minimum temperature in winter of $5^{\circ} \mathrm{C}$ and a mean maximum temperature in summer of $28^{\circ} \mathrm{C}$. Local agropastoral systems are low input systems based on small stock rearing (goats and sheep), and on unirrigated cereal cultivation (wheat and barley). Flocks are composed of 20 to 150 sheep and goats in various proportions. The local Berber inhabitants are linked to the famous Aït Atta nomadic tribal Confederation, but sedentarized in the 19th century.

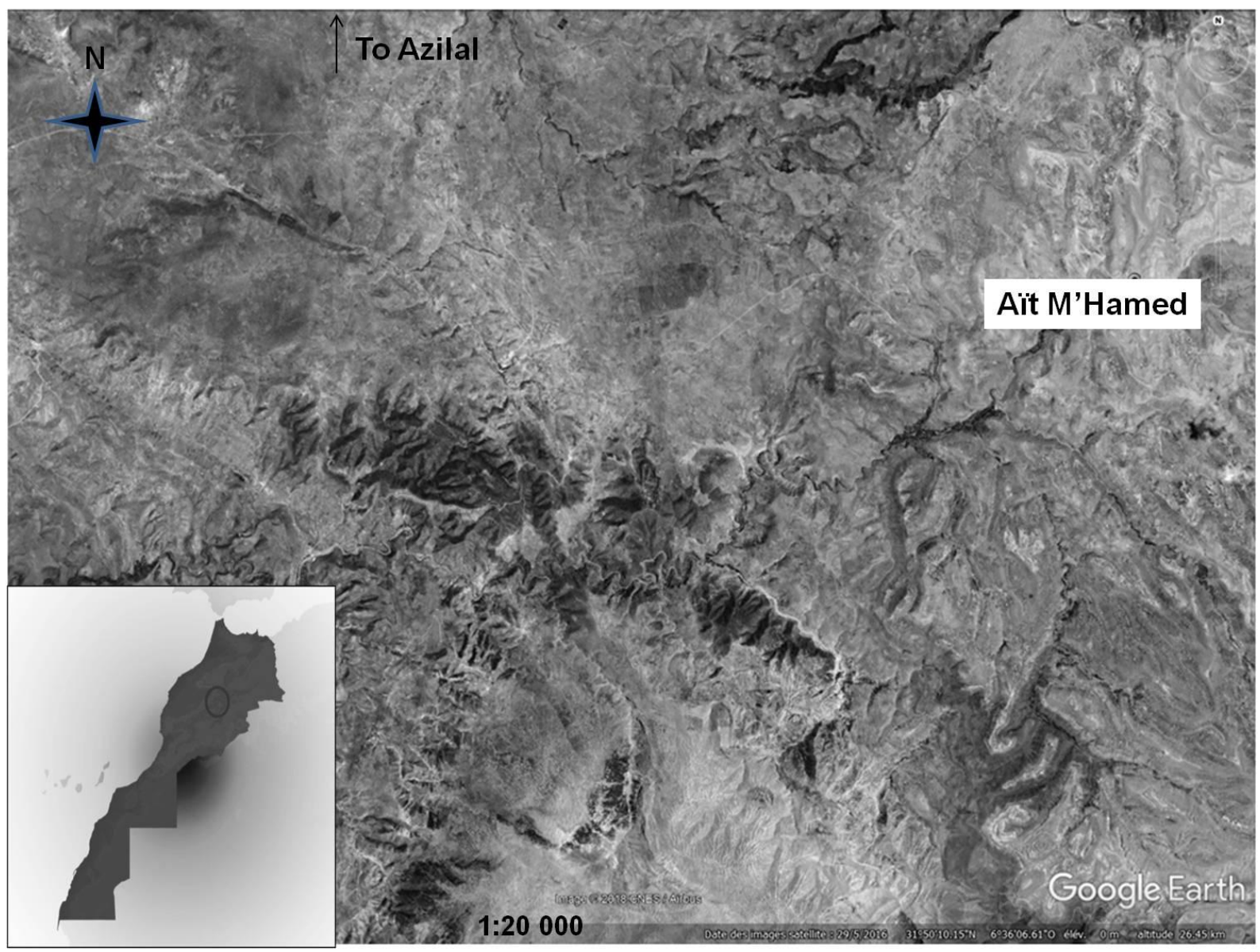


Figure 1: Location of the survey on the uses and management of Dimophic ash in the Central High Atlas of Morocco.

Forests occupy about $25 \%$ of the total territory of Aït M'Hamed, and are divided into two categories: those constituted in the coldest areas of the dimorphic ash, and those constituted of holm oak (Quercus ilex). These two species also occur together to form mixed forests and parklands. The structure of ash tree stands is of three types: 1) scattered trees (10 to 40 trees/ha) in the very harsh lapiaz plateau with calcareous flush rocks, 2) parklands or 'tree savanna'-like, as referred to by Boffa (1999), with a density ranging from 50 to 800 trees/ha, or 3) denser forests (1000 to 2000 trees/ha). Fraxinus dimorpha is always spontaneous, and it is never planted by the local inhabitants. Parklands are either cultivated with cereals in the understory, or not.

\subsection{Participant Ethnoecological survey}

Ethnobotanical and ethnobiological fieldwork was carried out in accordance with standard procedures issued by the International Society of Ethnobiology (2006), consisting of anthropological and ethnobotanical fieldwork methods such as participant observation and interviews. Fieldwork included semi-structured interviews and participant observations with 63 individual farmers (mainly male family heads) by means of snowball sampling (Biernacki and Waldorf 1981). They took place during the pollarding period, from August to November. Each interview was performed directly on parklands in the Berber language in order to facilitate information transmission, and lasted two to three hours. Information was obtained concerning 1) the structure of production means (number of trees owned, number of heads owned, fields and crops), 2) the actual pratices related to trees (number of branches cut per day in relation with the size of the flock, criteria of selection for individual trees to be 
exploited, rotation of cuts), and 3) representations about knowledge of the biology of trees and their interactions with livestock feeding, and about practices to be performed for safe cutting. For the purposes of this study, only data relative to tree management were mobilized here. More detailed analyses concerning the pastoral aspects of ash uses can be found in Genin et al. (2016).

\subsection{Ash tree stand physiognomy}

Due to the heterogeneity of the ash forms found in the landscape, we distinguished individual trees into 4 tree forms, based on the morphological aspect of the trunk: large anastomosed trunk trees, multi-stemmed or coppice trees (with clearly individualized stems with diameters of more than $10 \mathrm{~cm}$ ), single-stemmed trees, and shrub-like trees (stems not clearly indididualized and with stem diameter lower than $10 \mathrm{~cm}$ ). During each participant survey, three randomly chosen areas of $500 \mathrm{~m}^{2}$ were surveyed by means of either $100 \times 5 \mathrm{~m}$ or $25 \mathrm{x}$ $20 \mathrm{~m}$ bands, depending on the heterogenity of the stand, in order to characterize the proportions of the differents types of tree forms (Etienne 1989, Rondeux 1999). In practice, visual observation of trees alone sometimes proved insufficient to actually distinguish individuals when shoots were numerous, fragmented and mixed, and this made estimation of tree density hazardous. Hence, data presented here concern only proportions of the differents types of ash tree.

\subsection{Leaf productivity and tree management relationship}

A total of 320 resprouts were cut on regularly pollarded trees growing on a homogenous typical northen slope habitat of the ash, in order to assess the effect of trunk anatomosis on growth parameters. For each age of the latest cut during the pollarding cycle ( 1 to 4 years), 40 branches were taken from 4 mature ash trees (10 branches per tree), both on multi-stemmed 
and anastomosed trees. Measurements included basal growth of shoots in diameter, length of sprouts and foliar biomass.

\subsection{Data analysis}

Treatment of the participant survey was mainly qualitative, employing descriptive statistics to get a better understanding of the processes and practices associated with ash tree management; hence, considering proportions, or mean and standard error. Data resulting from quantitative measurements were processed following GLM procedures, evaluated for normality distribution, and linear correlation coefficients were calculated after logarithmic transformation (Snedecor and Cochran 1972) and tested for significance.

One- and two-way analyses of variance (ANOVA) were carried out, using the statistical SPSS package (version 17.0). Where the main effects were significant or interactions were detected with ANOVA, Walker-Duncan's test was applied. For each age of re-growth, Student t-test was used to determine the significance of differences between means of multi-stemmed and anastomosed trees (Snedecor and Cochran 1972).

\section{Results}

\subsection{Ash tree stand physiognomies}

Four types of ash stands can be distinguished: scattered trees found in areas with almost no soil on lapiaz plateau, parklands with cereal cultivation in the understory, uncultivated woodlands, and public forests officially under National Forestry Service management. Overall, proportions of these different tree stands in the landscape are 2, 34, 46 and 18\%, respectively. The first three types of ash stands are privately managed, although as they are considered as forest trees, any exploitation of ash trees should be authorized by the Forestry 
Services. In practice, ash trees in so-called recognized private lands are under the sole management of their owners. Whatever the type of tree stand, the physiognomic aspect of the dimorphic ash tree is highly heterogeneous, since at least four types of tree forms (large anastomosed trunk, multi-stemmed or mono-stemmed trees, and shrub-like trees) are concomitantly present (figure 2). The most remarkable feature is the presence of trees with large trunks formed by the combination of several stems. Informants told us that these are the result of the man-induced shaping of young trees that will be described below.

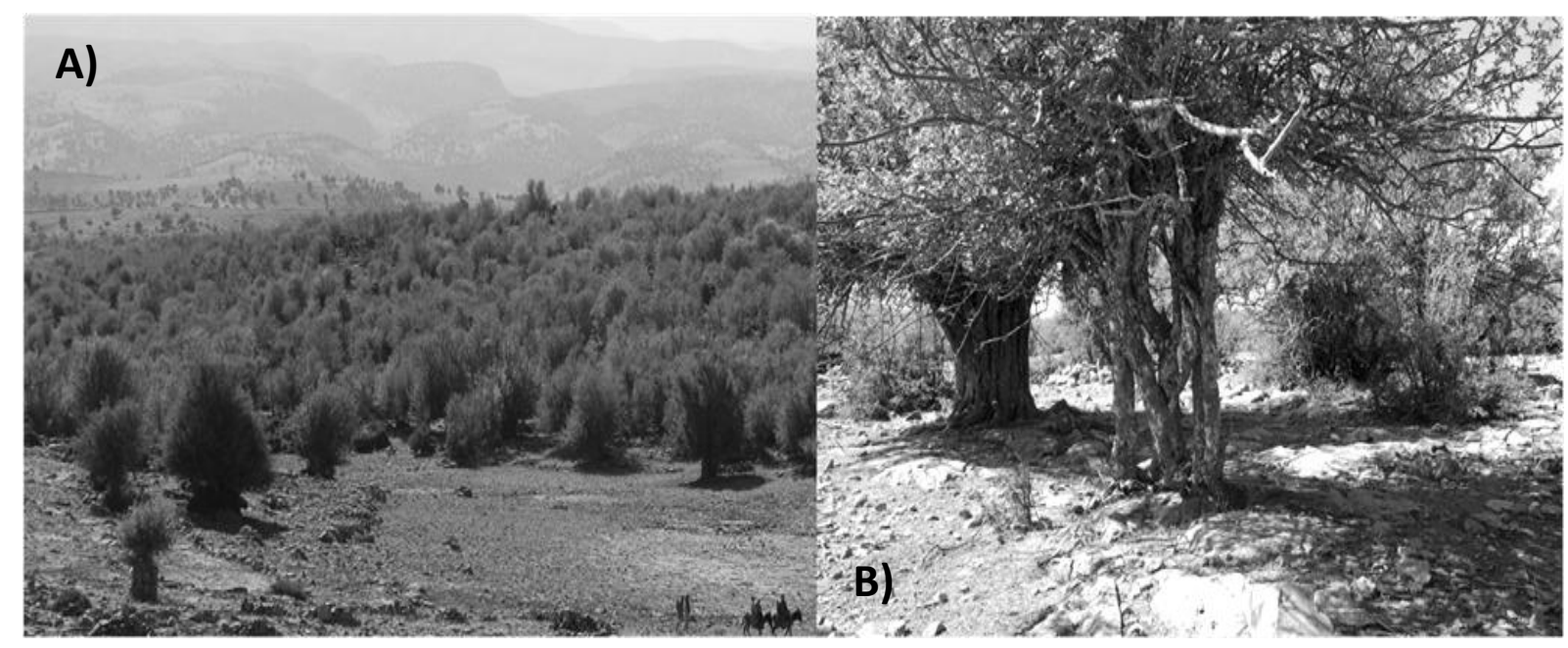

Figure 2: Overall scenery of Dimorphic ash tree forests (A), and heterogeneity of ash tree forms (B), particularly whose with large, thickset compartmentalized trunks (in the background left).

Table 1 shows that proportions of the different tree forms can vary widely, depending on the type of tree stand. Anastomosed trees are present mainly in cultivated parklands where they dominate (more than 50\%). They predominate even more in areas with scattered trees where the trees are almost all of this form (84\%) (Figure 3). The proportion of anastomosed trees is negatively correlated with estimated tree density $\left(\mathrm{r}^{2}=0.64, \mathrm{p}<001\right)$. In contrast, in public forests, the main ash tree physiognomy is in the form of shrubs (almost 58\%), indicating very 
high pastoral pressure on trees. Except single-stemmed trees, the other conformations of ash reflect significantly the type of ash stand they are located in.

\begin{tabular}{|c|c|c|c|c|c|c|}
\hline & $\begin{array}{l}\text { Cultivated } \\
\text { parkland }\end{array}$ & $\begin{array}{l}\text { Uncultivated } \\
\text { woodland }\end{array}$ & Public forest & $\begin{array}{l}\text { Scattered } \\
\text { trees areas }\end{array}$ & $\begin{array}{l}\mathrm{F} \\
\text { Value }\end{array}$ & Prob. \\
\hline \multicolumn{7}{|c|}{ Anastomosed } \\
\hline trees & $50.1 \pm 5 b$ & $16.2 \pm 2.2 c$ & $10.1 \pm 1.9 c$ & $84.2 \pm 9.9 a$ & 34.9 & $p<0.0001$ \\
\hline \multicolumn{7}{|c|}{ Multi-stemmed } \\
\hline trees & $21.2 \pm 3.4 b$ & $50.2 \pm 5.2 \mathrm{a}$ & $26.7 \pm 3.1 b$ & $4.6 \pm 3.4 c$ & 13.4 & $p<0.0001$ \\
\hline \multicolumn{7}{|c|}{ Single-stemmed } \\
\hline trees & $7.0 \pm 1.8 \mathrm{a}$ & $9.2 \pm 2.2 \mathrm{a}$ & $6.3 \pm 1.2 \mathrm{a}$ & $9.0 \pm 3.4 \mathrm{a}$ & 0.2 & 0.82 \\
\hline \multicolumn{7}{|c|}{ Shrub-like } \\
\hline trees & $21.7 \pm 4.1 b$ & $24.3 \pm 4.1 b$ & $57.9 \pm 3.7 \mathrm{a}$ & $2.2 \pm 1.9 c$ & 21.4 & $p<0.0001$ \\
\hline
\end{tabular}

Table 1: Analysis of Variance of proportions (in \%) ash tree forms according to their location in differentiated ash stands, and related statistics. Data were previously submitted to an Arcsine transformation. Values in line with different letters significantly differ at $\mathrm{p}<0.001$.

These differentiated proportions of the four tree forms induce typical and contrasted sceneries of four ash tree stands, as showed in figure 3. They intermix within the landscape and are places of production of differentiated tree resources. 


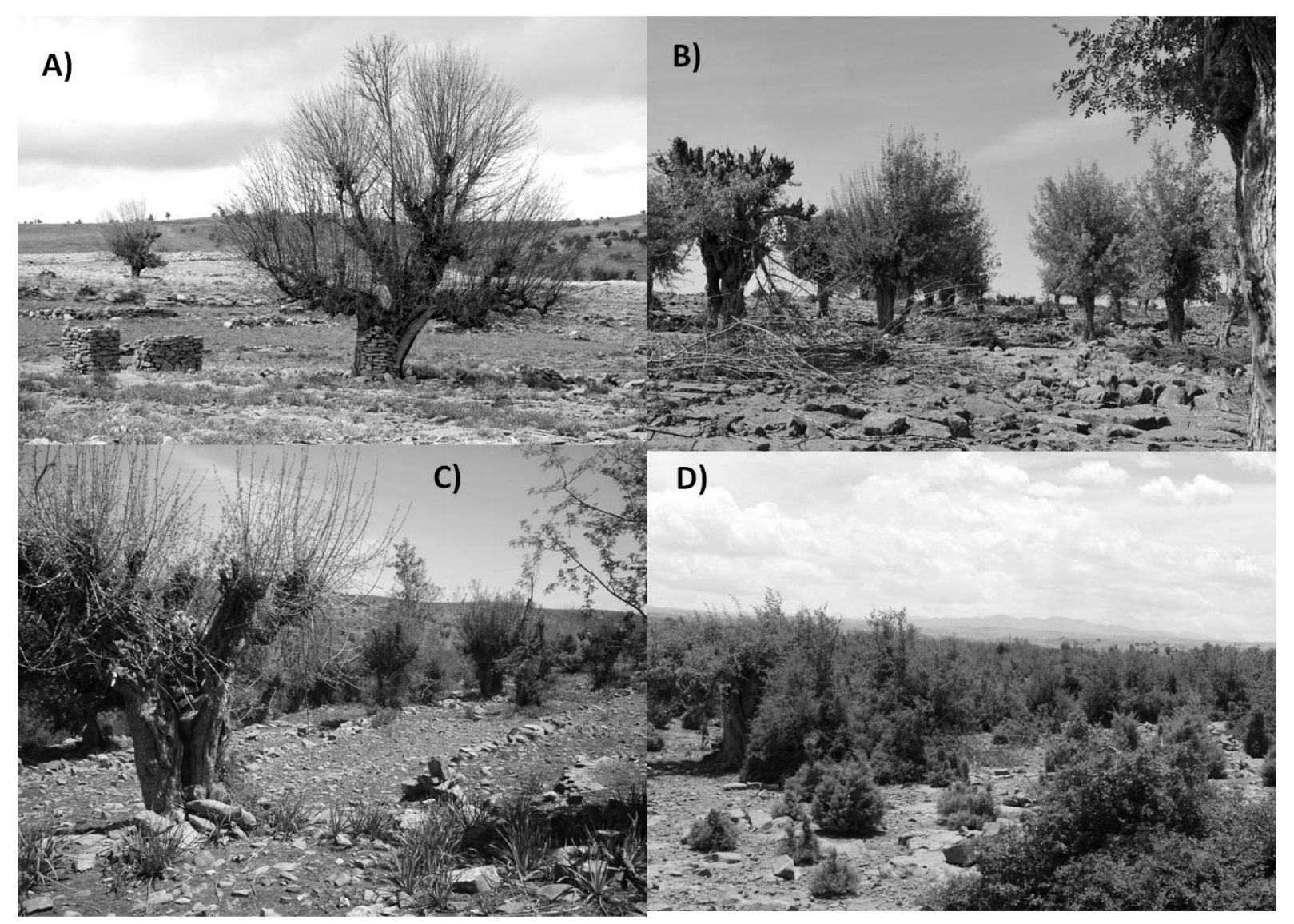

Figure 3: Four types of ash tree stands, with differentiated and integrated resources. A) scattered Ash trees highly shaped in order to provide both fodder, poles and beams; B) uncultivated woodlands for fodder production; C) cultivated parklands with cereal cultivation in the understory; D) public forest, heavily browsed by local flocks.

\subsection{Exploitation of trees and trade}

The main use of ash stands occurs from August until November for providing fodder for small stock. Trees are pollarded with a hatchet every four years in order to allow tree a sufficient growth. Leafy branches are browsed directly in fresh on the range by sheep and goats (Figure 4). A single tree is generally amputated of all its branches which can count to more than 250 . The number of branches actually cut in a given day is adjusted to the number of animals to be fed. Correlation coefficient between the number of branches cut daily and the size of the flock 
is $\mathrm{r}^{2}=0.71(\mathrm{n}=65, \mathrm{p}<0.001)$. Mean number of branches cut daily per head is 1.2 , but significant differences were found between flocks receiving fresh alfalfa as feed supplement $(0.9$ branch/head) or not (1.7 branches /head). These quantities correspond roughly to a contribution of ash foliage of 20 to $35 \%$ of the daily diet of the animals, respectively. Details concerning ash intake and nutritive value can be found in Genin et al. (2016). The number of branches cut per head and per day did not show significant correlation with the number of ashes owned $\left(\mathrm{n}=65, \mathrm{r}^{2}=0.12, \mathrm{p}>0.05\right)$.

Cutting occurs once a day in the morning for $88 \%$ of persons surveyed, while $12 \%$ (all owning more than 500 individual trees) declare repeating the operation in the afternoon. When they find particularly vigorous and straight branches (1 to 15 in a single tree), people commonly conserve and shape them by thinning out along a length of $3.5 \mathrm{~m}$. They will grow for four years more, and will conform after 8 years of growth calibrated poles of diameter of about $7 \mathrm{~cm}$ for the purpose of covering house roofs. Sometimes, particularly vigorous poles are conserved in order to produce beams in roughly 30 -year cycles. 


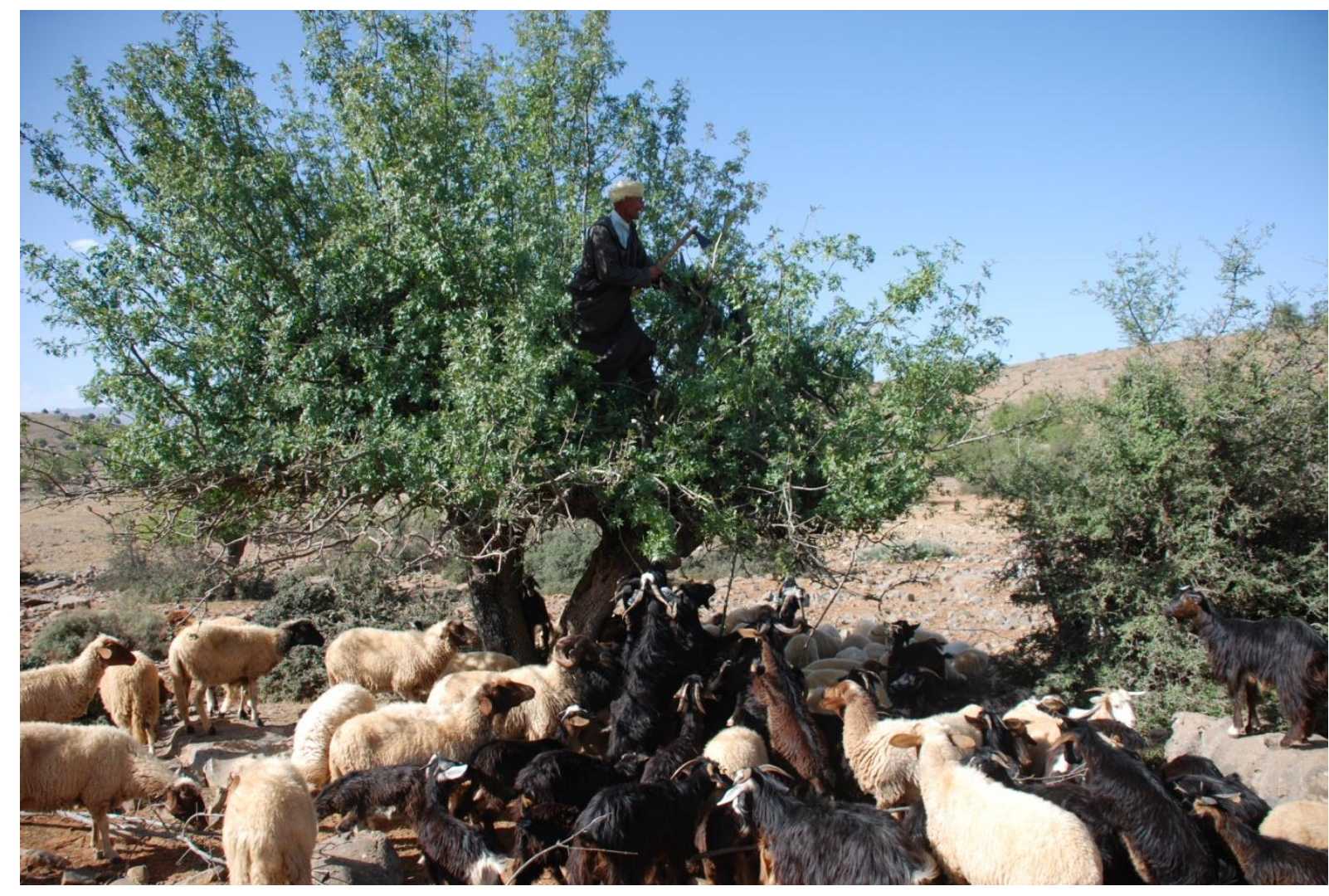

Figure 4: Pollarding dimorphic ash to feed small stock directly on the range

Since ash tree stands are mainly privately owned, pastoralists know exactly the number of ash trees they will be able to pollard, and hence can more or less accurately estimate the available amount of forage from trees. In a given parkland, only one fourth of the trees are pollarded each year, allowing a constant number of available trees to pollard each year according to the 4-year-cycle of tree exploitation.

Hence, on the same living tree, one can sometimes observe three differentiated 'floors ' corresponding to three types of resources (fodder, poles, beams), and sequentially harvested according to sophisticated nested cutting cycles (figure 5). This form of exploitation makes it possible to 1) provide annually diversified resources from living trees, 2) obtain 'calibrated' products as a result of shaping resprouts initially directly on the tree, and 3) estimate more or less accurately each year the availability of forage produced by trees. 


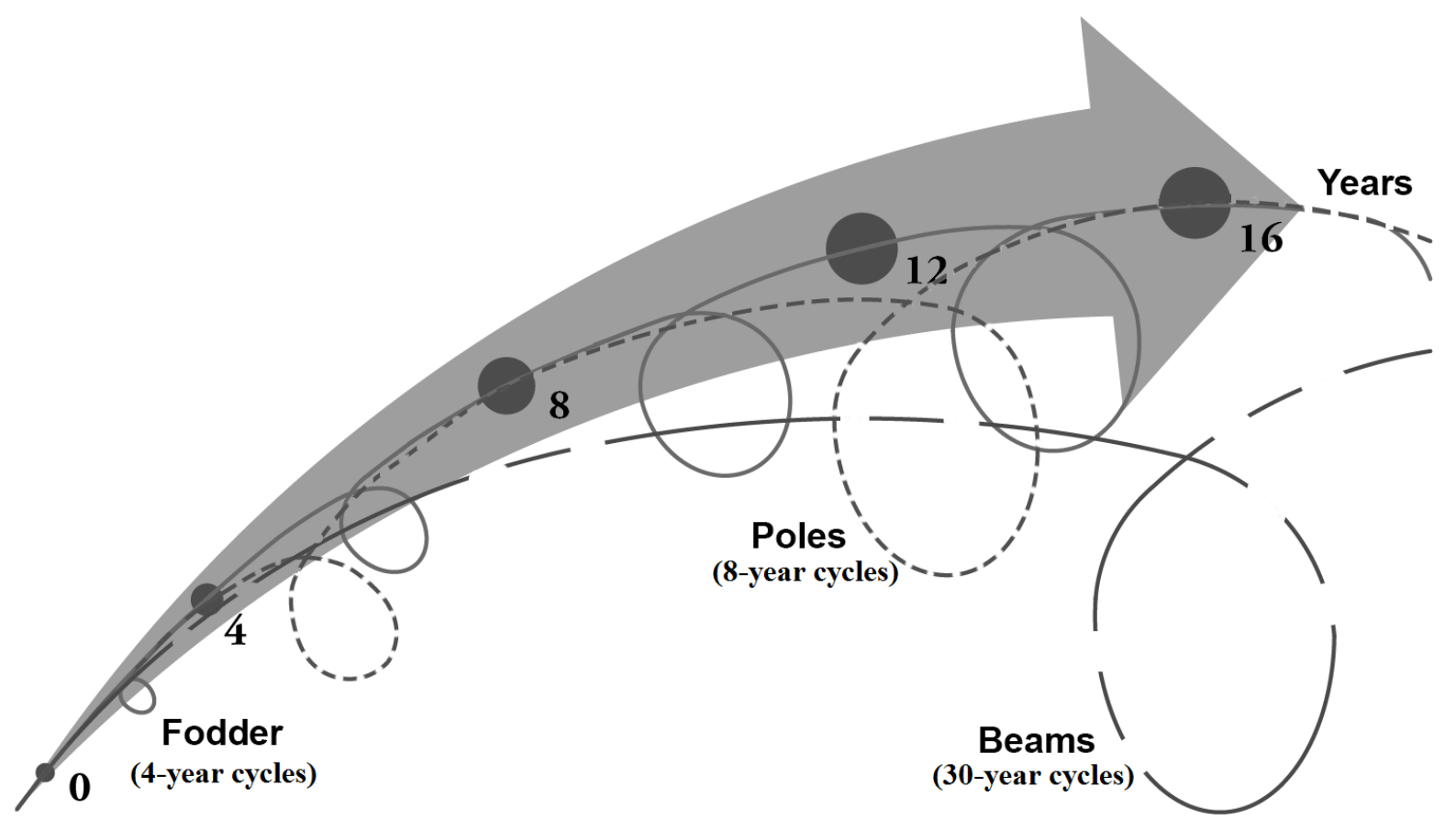

Figure 5: Nested cycles of ash products exploitation for fodder (solid line), poles (dotted line) and beams (interrupted line).

There is a local market for ash products. $15 \%$ of the panel declared buying fodder. The most usual means is by 'renting' trees for cutting during the cutting period $\left(25 \mathrm{DH}^{1} /\right.$ tree for small trees, up to $200 \mathrm{DH} /$ tree for very large trees). Twenty one percent of interviewees declared selling poles or beams (3 DH/pole; 40-50 DH/beam), and 32\% declared selling fruits in years when ash fruit production is abundant. In this case, two options were mentioned: selling fruits previously gathered by owners $(5 \mathrm{DH} / \mathrm{kg}$ for a mean production of $4 \mathrm{~kg} / \mathrm{tree})$, or renting a plot to outsiders exclusively for the harvesting of fruits (600 Dh/plot of about 100 trees).

\subsection{Tree regeneration: the practice of Tahboucht}

\footnotetext{
${ }^{1}$ The currency used in this paper is the Moroccan dirham. Approximate exchange rate: $11 \mathrm{DH} \sim 1 €$
} 
One of the most noticeable aspects of the tree management know-how and practices found in this region is related to the regeneration of overgrazed trees, and the protection of new seedlings or resprouts. The practice is locally called Tahboucht in Berber. This term is derived from the verb Habouch which means 'to educate', 'to mother'. It consists of building stone walls around the small trees in order to protect them against browsing, until they are above the maximum reach of sheep and goats (1.5-2m height). The protected coppice can thus grow normally by sprouting twigs from the collar of the tree. Only the most vigorous and straightest sprouting stems are then conserved (3 to 12), and are lopped in order to enhance the diameter growth of the stems. The stems are then moved and attached as close together as possible. In developing, they will become joined together, enter a process of anastomosis, and form a single large trunk composed of several stem compartments (figure 5). According to $69 \%$ of the local inhabitants surveyed, the aim of this practice is to enhance the tree's productivity and longevity.

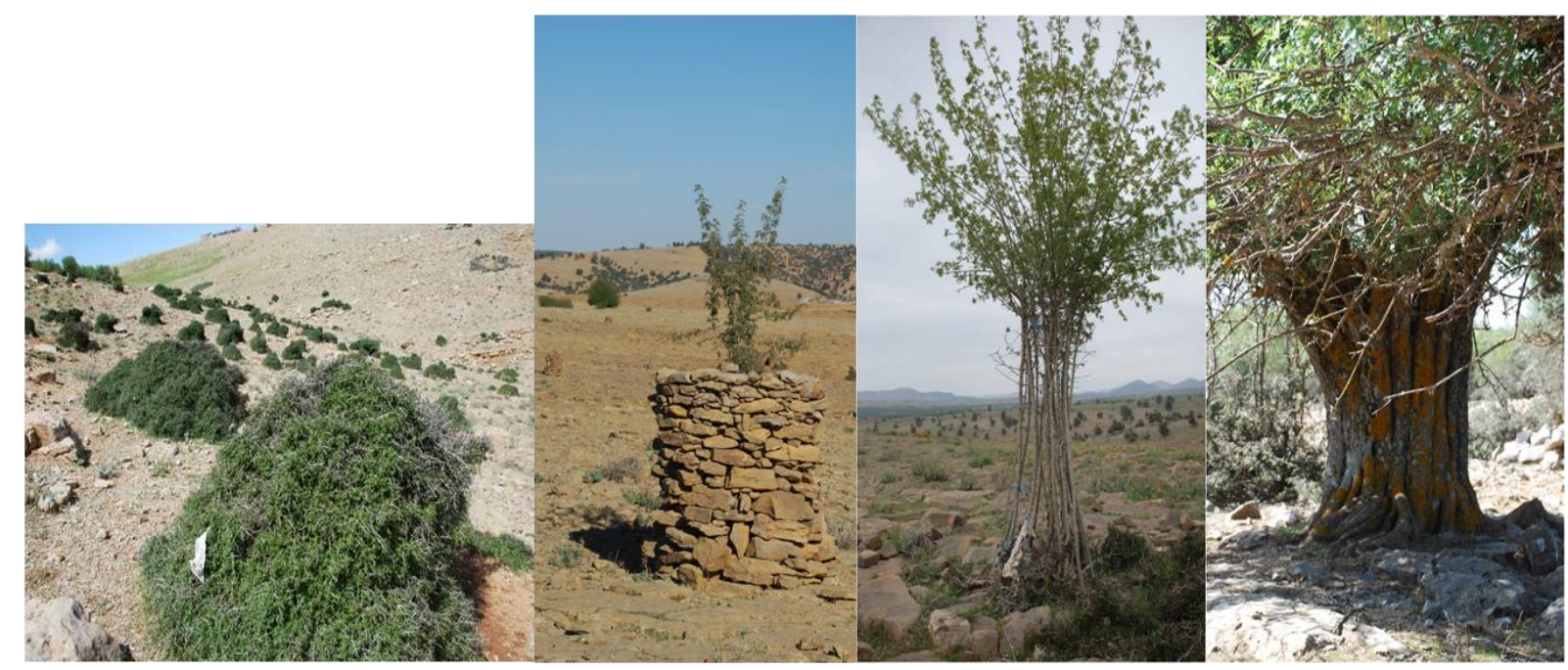

Figure 6: Sequence of protection of overgrazed ash tree by the technique of "Tahboucht", and shaping resprouts in order to favor trunk anastomosis. 
Only thirty-nine percent of the panel declared still practicing Tahboucht to regenerate trees, principally in the immediate surroundings of the farms, but said this practice was commonplace twenty-five years ago. The main reasons offered for the decline of this practice were: ownership of a sufficient number of ash trees (44\%), time-consuming (23\%), repeated destruction by goats (27\%), and because "regeneration is God's business" (6\%).

\subsection{Effects of trunk anastomosis on regrowth parameters}

The effects of trunk anastomosis on the radial and length growth of stems, as well as foliar biomass, are presented in table 2 for the four year growth between two cuts. Except for radial growth of shoots in diameter after two years of regrowth, all regrowth parameters showed significant higher values in case of anatomosed trees compared to multi-stemmed ones. Concerning growth in length, there is a clear advantage of anastomosed trees compared to multi-stemmed ones $(\mathrm{p}<0.001)$ with a difference of stem length after a 4-year growth of about 16\%. Leaf biomass presented highly significant higher values $(\mathrm{p}<0.001)$ in anastomosed trees compared to multi-stemmed ones in each year of the inter-cutting period, with a final increase of about $36 \%$ at the end of the 4-year cycle, confirming the statements of farmers that the aim of the practice of Tahboucht is promoving increased fodder production. 


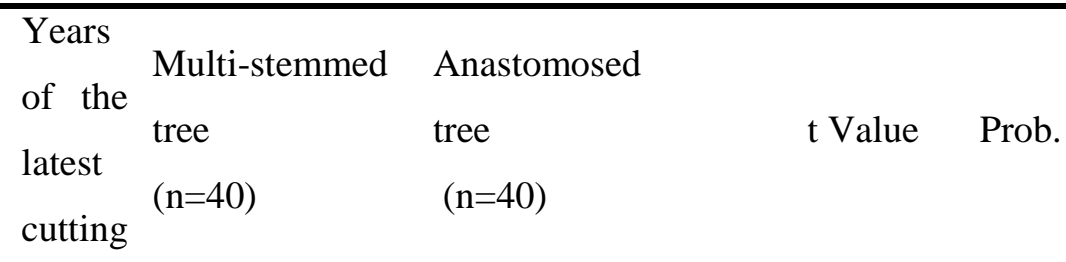

\begin{tabular}{|c|c|c|c|c|c|}
\hline \multirow[t]{4}{*}{ Shoot diameter $(\mathrm{mm})$} & 1 & $8.5 \pm 1.6$ & $9.8 \pm 1.53$ & $-7,72$ & $\mathrm{p}<0.0001 * * *$ \\
\hline & 2 & $13.7 \pm 1.1$ & $15.4 \pm 1.53$ & $-0,32$ & 0,749 \\
\hline & 3 & $18.5 \pm 1.7$ & $24.2 \pm 2.42$ & $-9,52$ & $\mathrm{p}<0.0001 * * *$ \\
\hline & 4 & $27.5 \pm 2.3$ & $30.9 \pm 2.79$ & $-6,97$ & $\mathrm{p}<0.0001 * * *$ \\
\hline \multirow[t]{4}{*}{ Shoot length $(\mathrm{cm})$} & 1 & $113.8 \pm 11.6$ & $140.3 \pm 22.62$ & $-6,95$ & $\mathrm{p}<0.0001 * * *$ \\
\hline & 2 & $191.1 \pm 24.3$ & $236.5 \pm 32.09$ & $-8,15$ & $\mathrm{p}<0.0001 * * *$ \\
\hline & 3 & $231.4 \pm 33.3$ & $286.5 \pm 31.36$ & $-6,35$ & $\mathrm{p}<0.0001 * * *$ \\
\hline & 4 & $327.1 \pm 17.7$ & $279.7 \pm 42.22$ & $-8,30$ & $\mathrm{p}<0.0001 * * *$ \\
\hline \multirow[t]{4}{*}{ Leaf biomass per shoot $(\mathrm{g})$} & 1 & $18.41 \pm 3.5$ & $30.3 \pm 7.83$ & $-2,78$ & $0,008 * *$ \\
\hline & 2 & $59.6 \pm 20.2$ & $71.2 \pm 15.22$ & $-3,53$ & $0,001 * *$ \\
\hline & 3 & $90.4 \pm 17.2$ & $161.4 \pm 38.78$ & $-8,48$ & $\mathrm{p}<0.0001 * * *$ \\
\hline & 4 & $207.5 \pm 54.8$ & $281.8 \pm 80.05$ & $-15,14$ & $\mathrm{p}<0.0001 * * *$ \\
\hline
\end{tabular}

Table 2: Effect of trunk anastomosis on regrowth parameters of mature ashes during the 4year cycle of pollarding.

\section{Discussion}




\subsection{Shaping trees and tree stand for enhancing livelihoods}

Physiognomy of ash tree stands in this area is not a monolithic one because this tree is a typical multi-functional species aimed at providing different types of resources, and differentially shaped as such in order to strengthen local livelihoods (Larsen 2005). Hence, ash tree stands are not viewed by locals as 'forests' or 'rangelands' or 'wood production areas', but as integrated functional spaces where opportunity is given to take advantage of this highly malleable genera of Fraxinus (Thiebaut 2007). This is traduced, at the landscape level, by the presence of four physiognomies of ash tree stands which all have their utility, and, at the individual plant scale, by a diversity of tree forms as a result of human shaping. These two aspects allow people to harvest each year resources from their ashes, and hence participate to secure the management of the overall farming system. Shrub-like trees have functions for browsing, as well as large anastomosed trunks for leaf harvesting in Autumn. Poles and beams are shaped with anticipation directly on the living trees in order to provide in future construction material. Created parklands with relatively low tree density, allow the cultivation in the understory, while ensuring the specific ecosystem services generally provided by trees (Jose 2009).

Anyhow, the pastoral function of the dimorphic ash tree constitutes the basis for management decisions relative to ash tree, particularly because its leaves present a good forage value (e.g. 70\% In Vivo Dry Matter Digestibility) for small stock during the critical period of autumn (Genin et al. 2016). This principal use is also reported in several other regions, and has also left its mark on the landscapes, such as those of the Pyrenean region where ash trees (Fraxinus excelsior) were always present in groves near the sheepfolds (Gibon et al. 2015). It serves as a buffer for the foraging calendar of stock, as well as offering material for everyday uses and ecosystem services for the overall social-ecological system. Further, we hypothesize that it is the presence of this tree that allowed the former nomadic Ait M'Hamed tribe to settle 
in this area, as an alternative to flock movements during the autumnal period of forage shortage. Pollarding techniques, and a very refined system of overlapping cycles of cut appear to be the key-element for an original and efficient tree management system. Mabey (1996) reported a simpler cutting system of $F$. excelsior found in Great Britain, based on a 10-year rotation, in order to obtain poles. Charlton et al. (2003) also mentioned incentive rotational cycles for the exploitation of New Zealand trees as fodder source, associating pollarding and coppicing. Similarly, some studies have also described the key role that trees can play in sustaining agro-pastoral and agro-forestry livelihoods, particularly in harsh environments such as high mountains and arid zones. Singh et al. (2015) described how the bear oak is the pillard of the functioning of a sustainable traditional social ecological system based on pollarding and TEK. Other examples in the Himalayan chain include tree species management (Rawat et al. 2010) or management systems such as sokshing, which are plots of forest land collectively managed where leaf litter is collected for cattle bedding and soil fertility management (Dorji et al. 2006, Siebert \& Belski 2015). In the arid Red Sea Hills, Andersen et al. (2014) described how pastoral societies tend the rare available trees (mainly Acacia species) for pastoral exploitation and conservation because they are crucial for their livelihoods. In subSaharan Africa, Petit (2003) analyzed the central role of mixed tree species found in so-called forested parklands for sustaining integrated agropastoral activities.

The case we have presented here is a remarkable example of the full integration of a native forest ecosystem within an agro-forestry system, where the divide between forest and agricultural area is tenuous, as commonly found in the Mediterranean biome (Fabbio et al 2003). Historically, the links between people and forests are very old, based on mutual adaptation, shaping, ecosystem mimicry and transformation (Moran \& Ostrom 2005; Blanco et al. 2015). The forms of interactions are diverse, and the classical divide between forestry and agriculture is much too clear-cut, and cannot describe the diversity and complexity of 
situations worldwide. There is a continuum between 'Nature' and 'Culture' (Descola 2005) in the physiognomy of current forests which may be insufficiently taken into account in the study of the structure and functioning of forests.

\subsection{Biology and ecology of trees and TEK}

Traditional Ecological Knowledge (TEK) represents a body of knowledge accumulated over many generations on the biology and ecology of natural resources through close interaction between people and their environment (Berkes et al. 2000). It has been built up overtime to take advantage of the available resources. Shaping forests and trees, together with preserving the forest nature of ecosystems, are traditional practices with long historical trajectories, commonly found in various environments, from the tropics to temperate and semi-arid areas (Michon et al. 2007; Genin et al. 2013, Siebert \& Belsky 2014). The techniques used are very old: for example, pruning for harvesting fodder has been depicted as early as the Egyptian New Kingdom (1539-1075BCE) (Andersen et al. 2014). Petit and Watkins (2004) mentioned that pollarding and shredding trees were widespread and common practices in Britain until the eighteenth century. Trees were an important source of fodder and their branches were regularly lopped so that sheep and cattle could eat their twigs and leaves. Boreal forests were also intensively exploited for fodder, by trimming, pollarding and lopping living trees (Slotte 2001). These techniques received poor attention among the scientific community because they were considered as harmful for plants (Petit \& Watkins 2004), and hence were poorly studied. During past decades, however, pollarded trees have been found to shelter a high biodiversity, particularly endangered saproxylic fauna (Sebek et al. 2013). Owing to their lower height, pollard trees are less susceptible to branches breaking and falling, as long as pruning is carried out periodically. Pollards thus tend to live longer than unmanaged trees (Rackham 2003). 
However, Schweingruber (2007a), working on trees which had never been previously pruned, described the anatomical modifications induced by pollarding, and insisted on the sudden growth reduction after pollarding.

Fontanier and Jonkers (1976) state that a severe pruning of the branches or stems is effective in delaying the onset of aging. It shortens the internal transport system and improves the supplying of the periphery with water and nutrients. This can be regarded as physiological rejuvenation. Pruning also induces younger buds or tissue to form normal or adventitious shoots, these being more juvenile than those removed. This can be seen as a kind of 'semiontogenetic' rejuvenation (Ferrini 2006). Pollarded trees are known to probably live longer than unmanaged trees (Mansion 2010). This is also well known from e.g. ancient European oaks, and may be explained by the fact that pollarding contributes to the tree's capability to sustain a large biomass, continuously rejuvenated (Rackham 2003). Andersen et al. (2014) also argued that tending and pollarding trees favored tree longevity, and that this longevity in dryland trees was critical to protect viable populations during recruitment 'bottlenecks', that continued renewal of branches by pruning prolonged the production of viable seeds. However, while some species can react positively to pollarding (i.e. Quercus, Platanus, Tilia, some species of Acer, Alnus, Fraxinus, Liriodendron, Morus, Ulmus), some others (Fagus and other Acer species) do not always tolerate this kind of pruning (Mattheck and Bethge, 1998). The hormonal framework of pollarded trees is deeply altered by the removal and activation of numerous meristems that are, at the same time, hormone producers and users. Cytochinin content and activity is very high in the growing shoots of pruned plants, while gibberellin content is relatively low in the bud break phase to significantly increase only later in the season. The increase in auxin and gibberellin synthesis promotes the development of the vascular system and activates nutrient transport, thus intensifying the growth of the new vegetation (Ferrini 2006). The all-important feature of pollarding is to establish a framework 
whereby all sprouts are cut back regularly and the plant is kept healthy through an appropriate management technique.

The question of the impact of man-made trunk anastomosis on plant physiology remains to be studied in greater depth. Schweingruber (2007b) described the anatomical changes resulting from tissue fusion, with an increase of the proportion of parenchymatous cells, and an increase of surface of the trunk section. Supporting the Berber farmers' assertion, we showed that joining resprout twigs in the early stages of the plant's life cycle seemed to promote an increased leaf productivity in mature anastomosed trees, but the mechanisms at work still have to be elucidated. We may formulate hypotheses to be tested concerning the larger overall diameter of trunks resulting from anastomosis - as shown in a picture of a sweet chestnut by Schweingruber (2007b, p.230) -, allowing higher sap flux, or profound changes of the allocation of nutrient resources resulting from a pooling of columns of sap. It appears, from the analysis of the location of different forms in trees, that the scarcer the tree resource is and therefore potentially more subject to pressure - the greater the proportion of anastomosed trees. This suggests that trunk anastomosis practices could constitute an original option for resource scarcity management developed by locals.

To return to TEK, the case we describe here required from the local inhabitants a long process of observations, trials and analogy efforts to bring to maturity a use and management system of this particular ash tree species. Hence, the Traditional Ecological Knowledge mobilized here encompassed different skills with regard to, both 1) the eco-physiological functioning of the trees, 2) climate and agro-pastoral seasonality, and 3) techniques for pruning and pollarding trees, as well as ensuring regeneration in a context of high pastoral pressure.

\subsection{Creating cultural and functional landscapes}


The combination of tree biology and ecology, TEK and the functionality of trees within agrosilvo-pastoral systems and livelihoods leads to the shaping of so-called cultural landscapes (Farina 2000). In the cultural landscape we described here, trees appear to be the principal factor at work for controlling the size and spatial arrangements of the different rural landscape components of the community area. Hence, trees are key structural and functional elements of these landscapes, especially trees whose natural form has been altered to provide a diversity of resources to humans (Berkes \& Davidson-Hunt 2006). Turner et al. (2009) provided an overview of these Culturally Modified Living Trees (CMT) worldwide, and their significance both in terms of household economy, landscape ecology and folk culture. This ash-based agroforestry system, based on the combination of diversified tree stands and tree forms, corresponds well to those cultural landscapes, described by Farina (2000), that have lasted on a long-term scale. They show ecological characteristics that contribute to the promotion of: 1) mutual natural and human processes feedbacks, 2) a certain environmental resilience due to a tempered human disturbance regime, 3) the maintenance of landscape patterns (diversity and heterogeneity of the land mosaic), as well as, 4) the conservation of some landscape processes such as the self-organizing character of the ecological matrix.

\subsection{Three aspects of TEK as a basis for another vision of sound tree and forest management}

There is usually a gap in the respective perception of what could be 'good' forest management between local stakeholders and professional foresters, which leads to frequent conflicts over the use and management of forested areas (Siskonen 2007, Michon et al. 2007). These discrepancies have to be analyzed and interpreted if the different points of view are to be reconciled. We have distinguished three main types of differences in the ways of thinking regarding sound forest management between local practitioners and professional foresters. 
4.4.1. Scales of management: individual trees and overall forested landscape vs tree stand

Conventional forest management is based on the scale of a stand, which corresponds to a homogeneous unit of surface area to which a certain number of variables are attributed, reflecting its economic or environmental value: the volume of wood per hectare, the vegetation cover, etc.

On the other hand, the logic of use in traditionally managed forests is only rarely based on the stand, but rather on the individual tree as a management unit, as well as on the village forest area as a whole, where the complementary uses of diversified resources are based on the same 'raw materials' that are constituted by the trees themselves.

Similarly, management of the time scale is very different: long tree exploitation cycles, rigorously planned centrally, for foresters, with long protection and processing phases aimed at the homogenization of forest stands; more diffuse but continuous use with annual cycles for local populations, and continuous adaptation to environmental hazards and local socioeconomic dynamics.

4.4.2. The partial (diffuse) exploitation of living trees vs intensive cycles of exploitations of the whole tree stand

Most often, logging by foresters consists of total felling of trees or stands, followed by regeneration practices. We have seen here that traditional exploitation of the forest's tree resources is mainly done by conserving living trees and by taking off only part of the biomass. These practices are considered in Morocco as "predatory" of resources, and, because Moroccan forestry law stipulates that it is prohibited to harvest live wood from living trees, outside the authorized concessions, they are qualified as criminal acts. This statement appears in reality to be largely nuanced, in view of the observations we have made and various studies 
throughout the world (rehabilitation of pollards in Europe (Mansion 2010), tree shaping practices in desert areas (Andersen et al. 2014), exploitation of NTFPs in North America (Berkes \& Davidson-Hunt 2006).

\subsubsection{Flexibility and pro-active management of heterogeneity vs homogenization}

When asked why they are going to carry out this or that practice on a tree, the agropastoralists explain that they make their decision according to the present situation: the natural bearing of the tree, possible phenotypic characteristics (the size of the leaves of an individual tree, well adapted to fodder, for example), the zone in which it is located, the type of resource sought, etc. They are constantly adapting to the micro-local situation and exhibit proactive management of heterogeneity rather than a desire to homogenize the forest area. From an ecological point of view, this position could be of interest because of the landscape diversity thus created, which is an asset for the expression of biodiversity. Further ecological studies should make it possible to provide evidence in this domain (Bhagwat et al. 2008).

\section{Conclusion}

Traditional Ecological Knowledge deployed in shaping dimorphic ash forests fulfills the two sets of basic principles that are characteristic of the traditional land use systems advanced by Herzog (1997) and Baldock et al. (1995). The first one, encompasses multiple and rotational uses, recycling, low-energy economy, and spatial fuzziness (Herzog 1997). The second one includes a slow rate of change that produces long periods of relative stability, management techniques that enhance the structural diversity of vegetation, the maintenance of a high proportion of semi-natural vegetation, and low use of agrochemicals (Baldock et al. 1995). Hence, though management is not explicitly oriented toward nature conservation, it includes several attributes of it. The resulting rural forests are most often managed informally by local 
populations, but constitute "forests 'to live' in that they integrate production and conservation within the social, political and spiritual dimensions" (Michon et al. 2007), for the society that uses them. Traditional exploitation and management practices also meet objectives and correspond to rationales that need to be better understood, and have impacts (negative or positive) on the physical and physiognomic components of forests. Despite their reputation, and sometimes their appearance of "degraded ", "poorly managed", or "unprofitable" forests, several examples mentioned here support the assertion that rural forests can also bear several qualities implicated in sustainable development. These include mimicry of natural processes (Blanco et al. 2017), more environmental-friendly practices as compared to typical agricultural or forestry ones (Michon et al. 2007, Siebert \& Belsky 2015), and specific balances between 'nature' and 'culture' (Genin et al. 2013). It is not a well-oiled model, whether in terms of biodiversity sanctuary, full governance and redistribution of benefit or wood production, but it does offer certain integrated partial benefits in all these domains. It also makes it possible to include other fundamental dimensions into forest management, such as the governance and the heritage-building of resources and landscapes.

In a new era of rethinking innovative forms of production and ecosystem mimicry, particularly with the increasing development of agro-forestry systems (Bhagwat et al. 2008), these forgotten practices can play a primary role as a basis for designing technical itineraries and for integrating the multiple dimensions of sustainable agri-food production approaches in our highly changing world.

\section{Acknowledgements}

This study was partly founded by the Med-Inn-Local program (ANR-12-TMED- 0001-01) of the ANR (Agence Nationale pour la Recherche, France). Thanks are due to IRD, LMI 
MediTer and Cadi Ayyad University of Marrakech for technical and logistical support. We are grateful to the inhabitants of Aït M'Hamed village for their cooperation, and especially to Saïd Oughzif for his precious help as a translator and a key facilitator. Michael Paul revised the wording of the manuscript.

Declaration of interest: none

\section{References}

Andersen, G.L., Krzywinski, K., Talib, M., Saadallah, A.E.M., Hobbs, J.J., Pierce, R.H., 2014. Traditional nomadic tending of trees in the Red Sea Hills. J. Arid Env. 106: $36-44$.

Auclair L., Baudot P., Genin D., Romagny B., Simenel R., 2011. Patrimony for resilience: evidence from forest Agdal in Moroccan high Atlas. Ecology \& Society, [en ligne], 16: 24, http://dx.doi.org/10.575/ES-04429-160424

Bhagwat S.A., Willis K.J., Birks J.B., Whittaker R.J., 2008. Agroforestry: a refuge for tropical biodiversity? Trends Ecol. Evol. 23(5): 261-267.

Baldock, D., Beaufoy, G., Clark, J., 1995. The Nature of Farming: Low Intensity Farming Systems in Nine European Countries. Institute for European Environmental Policy, London.

Berkes F., Davidson-Hunt I. 2006. Biodiversity, traditional management systems, and cultural landscapes: examples from the boreal forest of Canada. Int Social Sci. J. 187: 35-47.

Berkes F., Colding J., Folke C. 2000. Rediscovery of traditional ecological knowledge as adaptive management. Ecological Applications 10(5):1251-1262. doi:10.1890/10510761(2000)010[1251:ROTEKA]2.0.CO;2 
Biernacki P., Waldorf D. 1981. Snowball sampling: Problems and techniques of chain referral sampling. Sociological methods \& research 10(2): 141-163.

http://dx.doi.org/10.1177/004912418101000205.

Blanco J., Genin D., Carrière S. 2015. The influence of Saharan agro-pastoralism on the structure and dynamics of acacia stands. Agriculture, Ecosystems \& Environment 213: 21-31.

Blanco J., Michon G. Carrière S. 2017. Natural ecosystem mimicry in traditional dryland agroecosystems: Insights from an empirical and holistic approach. J. Env. Manage 204: 111122.

Blondel J. 2006 The "design" of Mediterranean landscapes: a millennial story of human and ecological systems during the historic period. Human Ecol. 34:713-730.

http://dx.doi.org/10.1007/s10745-006-9030-4

Charlton J.F.L., Douglas G.B., Wills B.J., Preeble J.E. 2003. Farmer experience with tree fodder. New Zealand Grassland Research and Practice Series 10: 7-15.

Davies D. 2005. Indigenous knowledge and the desertification debate: problematising expert knowledge in North Africa. Geoforum 36: 509-524.

Descola P., 2005. Par-delà nature et culture. NRF- Gallimard, Paris, 623p.

Dorji L., Webb, Shivakoti G. 2006. Forest property rights under nationalized forest management in Bhutan. Env. Conserv. 33(2), 141-147. doi:10.1017/S0376892906002979

Etienne M. 1989. Non destructive methods for evaluating shrub biomass: a review. Acta oecologica. Oecologia applicata 10(2): 115-128.

Fabbio G., Merlo M., Tosi V. 2003. Silvicultural management in maintaining biodiversity and resistance of forests in Europe - the Mediterranean region. J. Env. Manage.67: 67-76. 
Fairhead J., Leach M. 1995. False Forest History, Complicit Social Analysis: Rethinking Some West African Environmental Narratives. World Development 23: 1023-1035.

Farina A. 2000. The Cultural Landscape as a Model for the Integration of Ecology and Economics. Bioscience 50(4): 313-320.

Ferrini F. 2006. Pollarding and its effects on tree physiology: a look to mature and senescent tree management in Italy. In: Dumont E. (Coord.), Les trognes en Europe, Rencontres autour des arbres têtards et des arbres d'émonde. Maison Botanique Eds., Boursay, France, pp. 71-79.

Fontanier E.J., Jonkers H. 1976. Juvenility and maturity of plants as influenced by their ontogenetical and physiological aging. Acta Horticulturae, 427 p.37-44

Gauquelin T., Michon G., Joffre R., Duponnois R., Genin D., Fady B., Bou Dagher-Kharrat M., Derridj A., Slimani, S., Badri W., Alifriqui M., Auclair L., Simenel R., Aderghal M., Baudoin E., Galiana A., Prin Y., Sanguin H., Fernandez C., Baldy V. 2018. Mediterranean forests, land use and climate change: a social-ecological perspective. Reg Envir. Change 18(3): 623-636. DOI: 10.1007/s10113-016-0994-3

Genin D., Simenel R. 2011. Endogenous Berber forest management and the functional shaping of rural forests in Southern Morocco: implications for shared forest management options. Human Ecology 39(3): 257-269. http://dx.doi.org/10.1007/s10745-011-9390-2.

Genin, D., Aumeerudy-Thomas Y., Balent G?, Nasi R. 2013. The multiple dimensions of rural forests: lessons from a comparative analysis. Ecology and Society 18: 27.

Genin D., Crochot C., MSou S., Araba A., Alifriqui M. 2016. Meadow up a tree: Feeding flocks with a native ash tree in the Moroccan mountains. Pastoralism: Research, Policies. \& Practices 6: 11-26. 
Gibon A., Ladet S., Balent G. 2015. Diagnostic socioécologique de la gestion des prairies en référence aux services écosystémiques attendus des paysages dans le Parc National des Pyrénées (France). Fourrages 224 305-319.

Hammi S., V. Simonneaux, J.B. Cordier, D. Genin, M. Alifriqui, N. Montès, L. Auclair. 2010. Can Traditional Management Buffer Forest Depletion? Evolution of the Moroccan High Atlas Mountains' Forest Using Remote Sensing and Vegetation Analysis. Forest Ecol. Manage. 260: $1861-1872$.

Herzog, F. 1997. Stand der agroforstlichen Forschung in Westund Mitteleuropa. Z.

Kulturtechnik Landentwicklung 38 (4), 145-148.

International Society of Ethnobiology (2006). International Society of Ethnobiology Code of Ethics (with 2008 additions). http://ethnobiology.net/code-of-ethics/

Jose S. 2009. Agroforestry for ecosystem services and environmental benefits: an overview. Agroforest. Syst. 76:1-10.

Larsen J.B. 2005. Functional Forests in Multifunctional Landscapes. Restoring the Adaptive Capacity of Landscapes with Forests and Trees. EFI Proc. 53: 97-102.

Mabey R. 1996.Flora Britannica: The definitive new guide to Britain's wild flowers, plants and trees. London, United Kingdom: Sinclair Stevenson.

Mansion D. 2010. Les trognes, l'arbre paysan aux mille visages. Ouest-France Eds, Rennes, France, $143 p$.

Mattheck C., Bethge K. 1998. The mechanical survival strategy of trees. Arboriculture J., 22: $369-386$ 
McGregor H. V., Dupont L., Stuut J. B. W., Kuhlmann H. 2009. Vegetation change, goats, and religion: a 2000-year history of land use in southern Morocco. Quat. Sci. Rev. 28(15): 1434-1448. http://dx.doi.org/10.1016/j.quascirev.2009.02.012.

Michon, G., De Foresta H., Levang P., Verdeaux F., 2007. Domestic forests: a new paradigm for integrating local communities' forestry into tropical forest science. Ecology and Society, 12(2), < http://www.ecologyandsociety.org/vol12/iss2/art1/>.

Moran E., Ostrom E. 2005. Seeing the forest and the tree: human-environment interactions in forest ecosystems. the MIT Press, Cambridge, Massachussetts, 442p.

Parotta J.A., Agnoletti M. 2007. Traditional Knowledge: challenge and opportunity. Forest Ecol. manage. 249:1-4.

Petit S. 2003. Parklands with fodder trees: a Fulße response to environmental and social changes. Appl. Geogr. 23(2): 205-225. http://dx.doi.org/10.1016/j.apgeog.2003.08.008.

Petit, S. Watkins C. 2004. Forgotten peasant practices : tree pollarding in Great Britain. Etudes rurales $169: 197-214$.

Rackham O., 2003. Ancient Woodland: its History, Vegetation and Uses in England (revised edition), Dalbeattie, Castlepoint Press.

Rawat Y.S., Vishvakarma S., Oinam S., N.P. Todaria, Maikhuri R.K. 2010. Salix fragilis L.: Pollarding potential in dry temperate environment of the North-Western, Himalaya, India. Range Manage. Agroforestry 31(1):1-6.

Rondeux J. 1999. La mesure des arbres et des peuplements forestiers. Presses Agronomiques de Gembloux, Belgium, 516p. 
Schweingruber F.H. 2007a. Modification of the Tree-Ring Structure due to defoliation and Pollarding. In: Schweingruber F.H. Wood Structure and Environment. Springer, Berlin, pp.140-178.

Schweingruber F.H. 2007b. Modification of the Tree-ring due to deformed stems and anastomosis. In: Schweingruber F.H. Wood Structure and Environment. Springer, Berlin, pp.229-236.

Sebek P, Altman J, Platek M, Cizek L 2013. Is Active Management the Key to the Conservation of Saproxylic Biodiversity? Pollarding Promotes the Formation of Tree Hollows. PLoS ONE 8(3): e60456. doi:10.1371/journal.pone.0060456

Siebert M., Belsky J.M., 2015. Historic livelihoods and land uses as ecological disturbances and their role in enhancing biodiversity: An example from Bhutan. Biol. Conserv. 177: 82-89.

Singh R.K., Singh A., Garnett S.T., Zander D.K., Lobsang D.K., Tsering D., 2015. Paisang (Quercus griffithii); a keystone tree species in sustainable agroecosystem management and livelihoods in Arunachal Pradesh, India. Environmental Manage. 55: 187-204.

Siskonen H. 2007. The conflict between traditional and scientific forest management in 20th century Finland. Forest Ecol. Manage. 249: 125-133.

Snedecor, GW, Cochran W.C. 1957. Méthodes statistiques. Ames, Iowa, USA: The Iowa State University Press, 6e Edition.

Slotte H. 2001. Harvesting of leaf-hay shaped the Swedish landscape. Landscape Ecology 16:691-702.

Soule M. 2013. The "New conservation". Conserv. Biol. 27: 895-897 
Szabo P. 2010 Why history matters in ecology: an interdisciplinary perspective. Env.

Conserv. 37: 380-387.

Thiebaut L. 2007. "De la racine à la dernière feuille». Utilisations et représentations du frêne dans une commune des HautesPyrénées : quand humains et frênes se rencontrent. Licence Thesis, Univ. Neuchatel, Fac. Sci. hum., Switzerland, 143p.

Turner N.J., Boelscher Ignace M., Ignace R., 2000. Traditional Ecological Knowledge and Wisdom of Aboriginal Peoples in British Columbia. Ecol. Appl. 10(5): 1275-1287.

Turner N.J., Ari Y., Berkes F., Davidson-Hunt I., Fusun Ertug Z., Miller A. 2009. Culturally modified trees: an international perspective. J. Ethnobiol. 29:237-270. 